\title{
Implementation of Thematic Learning on Curriculum 2013 in 4th Grade Elementary School
}

\author{
Yusrina, H. ${ }^{1}$, Yamtinah, . $^{2}$, Rintayati,.$^{3}{ }^{3}$ \\ 1,2,3 Elementary School Teacher Education of Graduate Program, Sebelas Maret University \\ Corresponding email: husnanana23@gmail.com
}

\begin{abstract}
This study aims 1) to know the implementation of thematic learning on the curriculum 2013 in 4th-grade elementary school; 2) to know the needs of teachers in the implementation of thematic learning in 4th-grade elementary school. This study used qualitative research methods. The research was conducted in public elementary schools in the Gugus Pattimura, Klaten district which has been using the curriculum 2013. The subjects of the study were 4th-grade elementary school teachers. The data used to collect data is in-depth interviews, observation, and document analysis. The results of this research are: 1) All teachers have implemented thematic lesson in curriculum 2013. There are some teachers who still have difficulty in the implementation. Difficulties experienced by teachers, among others, in the making of the lesson plan, the implementation of thematic learning, assessment process, and develop the material in every learning. This is because of the needy costs, the amount of time required, and the teacher has other work to do besides teaching; 2) On the implementation of thematic learning, teachers still need other references to deepen the material and to develop the ability of learners to be more independent in learning activities and tailored to the competencies that must be achieved. The second requirement is that teachers need adequate facilities for the implementation of thematic learning can be maximized. In addition, teachers need regular coaching on the implementation of thematic learning so that learning activities can be given to learners maximally.
\end{abstract}

Keywords:Thematic Learning; Curriculum 2013; Education

DOI: $10.20961 /$ ijpte.v2i0.19822 


\section{INTRODUCTION}

Education in elementary school is the initial education of learners in building their knowledge widely by doing various activities that have been determined at every level. According to Santrock (2010: 107), elementary school education is the initial education of children interact and develop relationships with other children and at this level children get many sources of ideas to build children's understanding. At the elementary school level, there is a provision on the educational goals that must be achieved and controlled by the child at every level, where the provision has been determined by the government. Each child seeks to gain extensive knowledge in order to compete with children in different areas. The materials given at each level of education have been adjusted to the level of each level and according to the level of ability of the child at that age so that all the knowledge learned by the child can be accepted optimally. As the opinion of Santrock (2010: 40) who argue that education should be in accordance with the development of children because appropriate knowledge of child development will help provide understanding at the optimal level in the teaching and learning process.

At the present time, it is avery necessary innovation of teaching from teachers who are creative and skilled so that learners can carry out and get quality learning activities. Every child should be able to develop his ability to compete with others. Learning activities should be created by children anywhere and can be done independently. In elementary school children have started to develop themselves in accordance with its ability. Desmita (2014: 104) argues that at the elementary school stage they no longer rely on perceptions of vision but have been able to use logic. And not only in the school environment, an education and science education can be obtained in the environment around in everyday life. The environment also affects the learning activities of children, where a good environment can provide comfort and provide a fun atmosphere for learning.

The government, especially in Indonesia, always holds renewal in various fields of science, one of them is education science development. Renewal in the field of education is intended for the nation's generation has a broad knowledge and have good behavior. Development in the field of education is done so that learners can compete with other children, both nationally and internationally. Currently in many countries has done a lot of improving the quality of education so that they are easier and varied in applying their knowledge, but also to explore new science (McKnight 2016). Smith and Joshi (2016) argue that we can see some countries that have citizens with high education and science so that education and science can influence civilization and progress on the nation. It proves that the progress and high quality of a country can be sourced from education owned by citizens in the country.

Renewal in the field of education aims to improve the quality of education in each region and in various countries. In Indonesia is currently refining the curriculum in the field of education that aims to make the students good quality. In accordance with the opinion of Yardakul (2015) that the curriculum used in education is very important in providing educational services. So curriculum 
development is needed to be able to provide a broad knowledge for learners and make children have quality in the field of Education. The curriculum that is currently being developed and used in the educational environment is the curriculum 2013. The curriculum 2013 is a refinement and complement of the previous curriculum. This curriculum 2013 begins to develop learners to have a broad knowledge and can develop the capabilities possessed by each individual and can learn independently. The curriculum 2013 used uses thematic learning activities. Thematic learning is a learning that integrates the various competencies of various subjects into various themes (Kemendikbud, 2013: 9). According to Majid (2014: 86) thematic learning is an integrated learning that uses the theme as a unifying material in several subjects at once in one meeting. But not all schools apply thematic learning, just as many schools have already implemented. This thematic learning is used in order to provide opportunities for learners to be able to develop their knowledge in various ways according to their ability. One way that can be used so that learners can develop knowledge that is by reading various books and references, so that knowledge obtained and learned can be received optimally. In this curriculum is given material that has been adjusted to the level. In learning with the curriculum 2013 is expected to children can actively carry out learning activities and can independently seek knowledge broadly with the ability possessed.

From the above exposure can be concluded that each school has their own way of carrying out their learning even though they use the same curriculum. So this study aims to determine how is the implementation of thematic learning on the curriculum 2013 in the 4th grade of elementary school and determine the need for teachers in carrying out thematic learning in 4th grade of elementary school.

\section{METHOD}

The research method used is qualitative research method. Qualitative research is a research method used to examine the condition of scientific objects and research results that emphasize the meaning of the generalization (Sugiyono, 2015: 9). The result of this research is in the form of description. The population in this study is the public elementary schools in the Gugus Pattimura (Groups consisting of several Schools that have implemented the 2013 Curriculum as determined by the Education Office of Klaten District) that has implemented the curriculum 2013 in the period 2016-2017. The sample used in this research is 4th-grade teacher of elementary school.

Techniques used to collect data in this study using in-depth interview techniques, observation, and document analysis. Interview techniques are used to find out how the activities of teachers in implementing thematic learning for learners and to find out the needs of teachers in implementing thematic learning in order to support learners to gain broad knowledge and can understand all the material optimally in accordance with the learning objectives to be achieved. Observation technique aims to know the implementation of thematic learning in the curriculum 2013, both in terms of how teachers implement, know the constraints faced, and what needs are required for learning activities to be more optimal. 
Data collection instruments are interview guides, observation sheets, and document analysis sheets. Data obtained from various sources, either interview guides, or observation sheets, or document analysis sheets were validated using triangulation. Triangulation is a technique based on a phenomenological mindset that is multiperspective or to draw a solid conclusion and requires more than one point of view (Sutopo, 2002: 78). Analysis of data used to draw final conclusions on the results of data, both from interviews, observations, and documents using interactive analysis techniques from Miles \& Hubberman (2014: 14), namely: a) Data collection; b) Data condensation; c) Presentation of data (data display); and d) Conclusions.

\section{RESULT}

The results of this study one of them obtained from the observation of the implementation of thematic learning on the curriculum 2013 in 4th-grade elementary school. In the thematic lessons conducted by 4th-grade teachers have various differences in the delivery of materials in the classroom even though they use thematic learning activities. The following is a result of the observations found in the classroom when implementing thematic learning in 4th grade of elementary school in public elementary schools in the Gugus Pattimura that has been using the curriculum 2013:

Table 1. Observation Results of Thematic Learning Implementation

\begin{tabular}{llc}
\hline No. & \multicolumn{1}{c}{ Indicators } & Percentage \\
\hline 1. & Teachers use the curriculum 2013. & $100 \%$ \\
2. & $\begin{array}{l}\text { Teachers apply thematic learning in } \\
\text { accordance with the ones listed in the } \\
\text { curriculum 2013. }\end{array}$ & $100 \%$ \\
The teacher prepares the lesson plan \\
for every lesson in the classroom. \\
Teachers have difficulty in applying \\
$\begin{array}{l}\text { thematic learning in accordance with } \\
\text { the curriculum 2013 used. } \\
\text { Teachers use instructional media every } \\
\text { teaching thematic learning and always } \\
\text { adapted to that contained in the book. }\end{array}$ \\
$\begin{array}{l}\text { Books used both teachers and learners } \\
\text { only from the government alone. }\end{array}$ \\
\hline
\end{tabular}

The results of the observation of teachers in implementing thematic learning in 4th grade of elementary school can be found that all teachers in theelementary school of Gugus Pattimura have been using curriculum 2013. This is demonstrated by $100 \%$ of teachers already using the curriculum 2013 and has implemented thematic learning according to those set by the government's curriculum 2013. And all teachers use the lesson plan when they will implement thematic learning every day. There are $37.5 \%$ of teachers who are still experiencing difficulties in applying thematic lessons according to the curriculum 
2013 because they have a reason for each teacher in each region. Of the eight teachers observed, $75 \%$ of teachers have used the media required in the learning of each lesson. While the other teachers do not add the media in implementing learning using only books. And currently, $100 \%$ of teachers use teachers' books and government books on thematic learning.

The implementation of thematic learning in the curriculum 2013 has a different implementation process in each region. And each teacher has a different way of using when implementing learning in the classroom so that learning activities undertook by learners more fun and can achieve the expected goals in each learning. And the following is the result of interviews with 4th-grade elementary school teachers in implementing thematic lessons in the curriculum 2013 generated that:

Table 2. Table of interviews with 4th-grade elementary school teachers

\begin{tabular}{|c|c|c|}
\hline No. & Type of character taught & Percentage \\
\hline 1. & $\begin{array}{l}\text { The teacher uses the curriculum } 2013 \\
\text { in learning activities. }\end{array}$ & $100 \%$ \\
\hline 2. & The teacher uses thematic learning. & $100 \%$ \\
\hline 3. & $\begin{array}{l}\text { Teachers mastered the learning } \\
\text { activities by using thematic learning. }\end{array}$ & $87.5 \%$ \\
\hline 4. & $\begin{array}{l}\text { Teachers have difficulty in applying } \\
\text { thematic learning. }\end{array}$ & $37.5 \%$ \\
\hline 5. & Teachers need additional references. & $100 \%$ \\
\hline 6. & $\begin{array}{l}\text { Books used to meet the needs of } \\
\text { learners. }\end{array}$ & $62,5 \%$ \\
\hline 7. & $\begin{array}{l}\text { The scope of material in the book used } \\
\text { is limited. }\end{array}$ & $100 \%$ \\
\hline 8. & $\begin{array}{l}\text { Teachers need discussions, workshops, } \\
\text { and training on thematic learning well. }\end{array}$ & $62.5 \%$ \\
\hline
\end{tabular}

From the results of interviews with 4th-grade teachers at an elementary school in a public school Gugus Pattimura, it can be explained that all teachers use the curriculum 2013 set by the government. In the curriculum 2013, teachers are required to use thematic learning so that $87.5 \%$ of teachers have used thematic learning well in accordance with the expected conditions. But in the implementation, $37.5 \%$ of teachers find it difficult in implementing learning by using thematic learning. $100 \%$ of teachers argue that the material in the book used is still very limited so that teachers need other references to develop learning so that learners have extensive knowledge. There are some teachers who want a discussion with teachers and supervisors about good thematic learning so that teachers can improve themselves every carry out learning.

Document analysis results obtained that the implementation plan used teacher learning shows $100 \%$ using thematic learning and has been in accordance with the competencies that must be achieved in each learning. But not all the activities in the lesson plan implemented properly. The teaching materials used are in accordance with the provisions of the curriculum 2013 because the books are used 
by the government. Teachers have two books: teacher books and student books, and teachers focus more on student books. In each school an adequate student book is available, but sometimes learners do not bring to school so they have to share books with their friends. Student books used are not scribbled by learners on learning activities because they belong to the school. If learners do the exercises on learning activities, they should write in their notebooks.

\section{DISCUSSION}

The implementation of lessons learned by teachers in the Gugus Pattimura, especially those appointed by the government to use the curriculum 2013, has implemented lessons using the curriculum 2013. In the process of implementation, teachers already use the curriculum 2013 which has been adjusted with the provisions that must be implemented properly. It is shown that $100 \%$ of teachers in seven public schools in the same segment as Pattimura have implemented the provisions contained in the curriculum 2013. In Klaten itself, not all schools have implemented lessons using the curriculum 2013, only a few schools are used to develop education with the curriculum 2013. Before teachers implement the curriculum 2013, teachers conduct guidance on the curriculum 2013, especially in the Gugus Pattimura and $100 \%$ of teachers follow the guidance, both from the activities to be undertaken, what kind of learning and how to assess learners in this curriculum. Because all activities in the curriculum 2013 are different from the previous curriculum, so teachers are given insight into everything related to the curriculum 2013.

In the curriculum 2013, implementation of learning uses thematic learning. They carry out learning in accordance with the existing learning in the curriculum 2013 that is thematic learning. All teachers have implemented thematic learning on school activities. Some teachers have mastered the implementation of thematic learning that has been determined in the curriculum 2013. But there are some teachers who still lack the mastery of learning activities on thematic well, but teachers deliver separate materials in each lesson. Teachers who have not mastered the thematic learning provide the material to the learners separately on each lesson, but the implementation remains in line with the competencies that must be achieved in each lesson.

In the learning activities, teachers are always in demand to be able to prepare lesson plans that will do every day. All teachers use the lesson plan for each learning activity. Most teachers use the lesson plan acquired from the internet instead of making their own lesson plan. The most important thing for the teacher that the material can be given to the students in accordance with the book. Because many children are less active in learning activities, so learners wait for the teacher command first to carry out the learning activities. So that the learning activities will be different for each teacher, depending on the lesson plan that has been made. There are many things that make teachers download lesson plan from the internet, one of which is the activities of teachers who are not only limited to the class, but there are other responsibilities, other than that the lack of infrastructure in the school that causes teachers to implement different learning 
from its lesson plan, And the teacher takes a long time to create his own lesson plan for each lesson.

In the implementation of thematic learning, teachers use books provided by the government that is required to develop their own learning activities. Although in the teacher's book there are directives about the use of other media to convey material to learners, but not all teachers use the media directed in the book. Some teachers are using other media that exist around the learner so that learners understand the material to the fullest. If the required media are difficult to obtain and cost a lot, the teacher gives them orally and sometimes gives pictures of media examples related to the material being taught to implement thematic learning to the maximum extent possible. Most teachers in the Gugus Pattimura only use books from the government for learning activities. Teachers develop materials using books in the previous curriculum, but only on certain materials. This is because the teacher has other tasks that must be completed so do not have time to seek the development of materials in every learning. In line with Ningrum and Sobri (2015) who said that obstacles faced by teachers in implementing the curriculum 2013 are teachers difficulty in making lesson plans, lack of time to deliver materials in each lesson, difficulties in dividing the time between teaching and completing the administration of the Curriculum 2013 quite a lot, and as well as the scoring system of learners.

In the implementation of thematic learning, there are still some teachers who have difficulty in applying it. From the results of interviews with teachers and observations there are $37.5 \%$ of teachers still have difficulty delivering the material with thematic learning. Teachers still have difficulty in delivering the material by using thematic learning. Teachers need additional material that is packaged in accordance with the implementation of thematic learning to be used in each lesson as an adjunct or supplement to the book used in the school. As well as teachers are still experiencing difficulties in the administration of assessment of learners used in the curriculum 2013. According to Krissandi and Rusmawan (2015), the implementation of the curriculum 2013 still has several obstacles such as book distribution, appraisal, socialization, infrastructures, and learning-learning instructional guidance, and teachers' understanding of thematic learning activities.

Constraints that cause teachers have difficulty developing the material is because they have other activities both at school and in the community so that teachers do not have a lot of time to find the materials contained in every learning. The teacher only develops material in some of the lessons that are in the book used in the lesson. Though the implementation of thematic learning to make learners the spirit of learning, more active in increasing knowledge, and develop themselves both learn with teachers and seek the development of material independently. While there are some learners who tend to be passive in implementing thematic learning, just waiting for material from the teacher. But there are learners who are always active follow the learning activities as well as they are also looking for material independently to expand knowledge. So the teacher should be able to develop the material in accordance with the competencies that must be achieved by learners. Furthermore, teachers also have difficulty in carrying out the assessment because there is no provision for assessing students. So the teacher 
makes the assessment of learners in two ways, namely assessing each subtopic and teachers also make the assessment of learners in each subject taught.

Difficulties in implementing thematic lessons that exist in the curriculum 2013, teachers have a need that is expected to make learning activities in schools to be meaningful and provide materials tailored to the competencies that must be achieved. The results of the data obtained states that teachers need additional references that match the competencies in each learning as an addition or complement of the book used. And the reference can be used learners independently to deepen the material on each learning. Similar to Arends (2013: 20) stating that effective teaching in the 21 st century is to provide insights on the way learners learn, the ultimate goal in learning activities, and about teachers in teaching. And according to Slavin (2011: 144) that the creation of an effective learning environment such as teachers should be able to present an interesting learning and neatly arranged. Currently, teachers have not found thematic references that can support thematic learning in the curriculum 2013 so as to develop the material in the lesson, the teacher takes the material in the books in the previous curriculum. Not all materials can be developed by the teacher, only a few materials are developed by teachers from books in the previous curriculum. Because the teacher must take a lot of time to find materials that are appropriate to thematic learning to match the competencies that must be achieved in each subtopic.

The needs of other teachers in implementing thematic lessons are adequate facilities to support the implementation of thematic learning in the curriculum 2013. It is expected that learners can understand the material and can develop themselves optimally. In this thematic lesson, not only teachers looking for infrastructure facilities are listed in the activities in the book in each learning, but the teacher must also be able to develop their own materials to be delivered to learners can be accepted optimally. If there are a means of infrastructure to support the school's learning, but the number is not sufficient in accordance with the number of learners so that learners do not understand the material to the fullest. In accordance with the opinion Scholz (2016) who said that infrastructure facilities can improve access of learners in studying in elementary school. In addition, the needs of other teachers are the regular coaching on the implementation of learning activities so that learning can be given to learners to the fullest. In addition, it is expected that all learners can be active in implementing learning with adequate facilities and the teacher can develop learning in every day.

\section{CONCLUSION}

Based on the results of research and discussion it can be concluded, all teachers have implemented thematic lesson in curriculum 2013. There are some teachers who still have difficulty in the implementation. Difficulties experienced by teachers, among others, in the making of the lesson plan, the implementation of thematic learning, assessment process, and develop the material in every learning. This is because of the needy costs, the amount of time required, and the teacher has other work to do besides teaching. And the implementation of thematic 
learning, teachers still need other references to deepen the material and to develop the ability of learners to be more independent in learning activities and tailored to the competencies that must be achieved. The second requirement is that teachers need adequate facilities for the implementation of thematic learning can be maximized. In addition, teachers need regular coaching on the implementation of thematic learning so that learning activities can be given to learners maximally.

\section{ACKNOWLEDGMENT}

We would like to thank the teachers of the 4th grade of public elementary school Gugus Pattimura in the period 2016-2017 which has given us the opportunity to observe the learning activities in the classroom. And also the teachers have taken time off to be interviewed by us to give their opinion on thematic learning. And also we would like to thank the principal of the existing public elementary school in the Gugus Pattimura which has given us the opportunity to conduct research and provide support for our research.

\section{REFERENCES}

Arends, R. (2013). Belajar Untuk Mengajar Edisi ke Sembilan buku 1. Jakarta: Salemba Humanika.

Desmita. (2012). Psikologi Perkembangan Peserta Didik (Panduan bagi Orang Tua dan Guru dalam Memahami Psikologi Anak Usia SD, SMP, dan SMA. Bandung: PT Remaja Rosdakarya.

Kemendikbud. (2013). Kurikulum 2013: Kompetensi dasar Sekolah Dasar (SD)/ Madrasah Ibtidaiyah (MI). Jakarta: Kemendikbud.

Krissandi, A.D.S., and Rusmawan.(2015). Kendala Guru Sekolah Dasar dalam Implementasi Kurikulum 2013. Jurnal Cakrawala Pendidikan Edisi Oktober 2015, Th. XXXIV, No. 3(2015), 457-467. DOI: 10.21831/cp.v3i3.7409.

Majid, A. (2014). Pembelajaran Tematik Terpadu. Bandung: PT Remaja Rosdakarya.

McKnight, A. (2016). Preservice Teachers' Learning With Yuin Country: Becoming Respectful Teachers In Aboriginal Education. Asia-Pacific Journal of Teacher Education, Vol. 44, No. 2 (2016), pp. 110-124.

Milles, M.B., Hubberman, A.M., \& Saldana, J. (2014). Qualitative Data Analysis: A Methods Sourcebook. Thousand Oaks: Sage Publications.

Ningrum, E.S., and Sobri, A.Y. (2015).Implementasi Kurikulum 2013 di Sekolah Dasar. Jurnal Manajemen Pendidikan, Volume 24 Nomor 5 Maret 2015, ISSN 0852-1921, pp 416-423.

Santrock.(2010). Psychology Pendidikan Edisi 2. (Penerjemah Tri Wibowo). Jakarta: Kencana Prenada Media Group.

Scholz, C.L. (2016). A Study of the Application of a Bring Your Own Device Strategy in an Elementary School. Walden Dissertations and Doctoral Studies. http://scholarworks.waldenu.edu/dissertations. 
Slavin, R.E. (2011). Educational Psychology Theory and Practice (9th ed). Boston: Pearson.

Smith, W.C., \& Joshi, D.K. (2016). Public Vs. Private Schooling As A Route To Universal Basic Education: A Comparison Of China And India. International Journal of Educational Development, 46 (2016), 153-165.

Sugiyono. 2015. Metode Penelitian Kuantitatif, Kualitatif, dan R\&D cetakan ke22. Bandung: Alfabeta.

Sutopo, H.B. (2002). Metodologi Penelitian Kualitatif Dasar Teori dan Terapannya dalam Penelitian. Surakarta: UNS Press.

Yurdakul, B. (2015). Perceptions of Elementary School Teachers Concerning the Concept of Curriculum. Educational Sciences: Theory \& Practice, February 15(1) 2015, pp 125-139. 